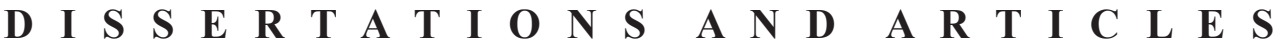

Saeculum Christianum

vol. XXIV (2017)

pp. $3-14$

\author{
TADEUSZ KOLOSOWSKI SDB
}

Faculty of Historical and Social Sciences

Cardinal Stefan Wyszyński University in Warsaw

\section{CARE FOR THE SICK IN ANCIENT MONASTERIES IN THE LIGHT OF SELECTED MONASTIC RULES}

\section{Introduction}

The first form of monastic life, which emerged at the turn of the 3rd and 4th century, was anachorite. It consisted in the anchorite monk going to a secluded place, most often a desert, where, with only what nature gave him as food, he devoted himself to prayer, reading the Holy Bible, and ascetic practices ${ }^{1}$. Slightly later the first cenobitic congregations were established. Cenobitism differed from anachorite mainly in the fact that the monks lived in a community in a closed monastery ${ }^{2}$ and their lives were subordinate to the monastic rule. This rule "defined every aspect of a member's life. Food, work, prayer, clothes, rest are all inscribed in the schematic rhythm of the monastery life" 3 . In his book on the ethical aspects of ancient medicine, P. Ashyk notes: "Many ancient religious rules instructed the monks in detail about their life, the rules of monastery functioning, the ascetic discipline in the communities giving their lives to God. The monks and nuns were subjected to very strict discipline, daily duties and mortifications were precisely specified. An organized religious community was intended as an efficiently managed structure, largely self-sufficient, organizing every aspect of its members from the moment they woke up to sleep" .

This article attempts to answer the question of how Eastern and Western monastic rules normalized the life of sick people in ancient monasteries. Did they enjoy any special status among their brothers or sisters? What people in the monastery and how were responsible for the care of the sick? In this respect, the monastic rules are an interesting and unique source of information about the actions taken with regard to the sick members of a religious community who needed care ${ }^{5}$. We thoroughly analysed several monastic rules from this perspective. These rules were established in various regions of the then world: Egypt, North

\footnotetext{
Cfr. J. Dziewulski, Życie codzienne mnicha cenobity w Egipcie na podstawie “Reguty” św. Pachomiusza, "Seminare", 31/2012, p. 243.

2 Cfr. Ibidem.

A. Kowalska, Ciało a struktura społeczna. Przypadek wczesnochrześcijańskiego monastycyzmu egipskiego, "The Polish Journal of the Arts and Culture", 1/2013, no 4, p. 41.

4 P. Aszyk, Etyczne oblicza starożytnej medycyny. Wczesne chrześcijaństwo wobec przedchrześcijańskich wzorców moralnych zwiqzanych z uprawianiem sztuki leczenia, Warszawa 2010, p. 94.

5 Cfr. Ibidem.
} 
Africa, Gaul, Italy, and Spain. They were established between the $4^{\text {th }}$ and $7^{\text {th }}$ centuries and concerned monks and virgins.

\section{The Pachomius rule}

Pachomius, commonly regarded as the father of cenobitism, was born around 292 in the village of Sne in Upper Egypt to a wealthy, rural pagan family. This was probably the reason for which he mastered, apart from Greek, the Coptic language. In 312 he participated as a soldier in Maximinus Daia's campaign against Licinius. Captured as a prisoner of war near Thebes, he experienced the kindness of Christians there. Seeing their attitude, he wished to become a Christian himself. This materialized itself about a year later when he settled in the village of Seneset after being released from prison. Soon, he decided to become an anachorite at the side of another hermit, Palemon. 10 years later, he moved to Tabenna. There, a community gathered around him to imitate him. That is why around 324 he started forming an organizational framework to the community gathered around him. In the years 329-340, he founded five monasteries and joined three communities at their request ${ }^{6}$.

To regulate monastic life, it was necessary to provide an appropriate rule of life. As the problems and difficulties of the cenobitic life grew increasingly significant, and more experience was gained, regulations were created, although quite chaotically at first. However, gradually the Rule of St. Pachomius was shaped and later supplemented with new regulations by his successors. For this reason, the whole text of the Rule did not constitute any kind of organically cohesive and logically arranged scheme. A practical attitude replaced a systematic approach. With present research, it is difficult to determine which provisions come from Pachomius himself, and which from his successors, as well as when the Rule was completed. It consists of four parts: The Commandments (Praecepta), the Commandments and Resolutions (Praecepta et Instituta), the Commandments, and Legal acts (Praecepta atque Iudicia) and the Commandments and Laws (Praecepta ac Leges). The oldest form of the Rule remains unknown. It is only known that it was edited in the Coptic language because basically Gauls were accepted into this community. It contained only a few provisions, rather general in nature, which were supplemented or modified as necessary with new ones. The piece in its entirety was only preserved as a Latin translation by St. Jerome, written ca. 404. Thanks to this translation, it has spread to the West. It is assumed that St. Jerome was the first to exactly preserve the order of the text, but it is not certain whether the translation was accurate and took into account all the regulations?

In Pachomian monasteries, there was a specially designated place called the sick chamber (locus aegrotantium) ${ }^{8}$ intended for the sick. In the Rule, there were also other terms used to describe the room of patients: cella languentium ${ }^{9}$, cella aegrotantium ${ }^{10}$, and

\footnotetext{
6 Cfr. V. Desperez, Wstęp, in: Pachomiana Latina, ed. M. Starowieyski, Kraków 1996, p. 15; J. Dziewulski, op. cit., p. 243-244.

Cfr. M. Kanior, Historia monastycyzmu chrześcijańskiego, vol. 1: Starożytność, Kraków 1993, p. 63-64.

8 Compare Pachomiusz, Reguta, 42, translated by A. Bober, in: Pachomiana Latina, ed. M. Starowieyski, Kraków 1996, p. 136.

9 S. Eusebii Hieronymi, Translatio Latina Regulae Sancti Pachomii, 52, Patrologia Latina [later referred to as: PL] 23, 71 .

10 Ibidem.
} 
locus infirmorum ${ }^{11}$. Some of the researchers (Andrew Crislip) are also of an opinion that the chambers were prototypes for the hospitals created by Basil the Great in the $470 \mathrm{~s}^{12}$. A special dining room (triclinium aegrotantium) was also available to patients ${ }^{13}$. The patients went there accompanied by nurses and ate their meals there ${ }^{14}$. The superior (praepositus) was responsible for special care for the patients. There were nurses (ministri aegrotantium) intended to support him ${ }^{15}$. The nurses had at their disposal everything they needed to care for the sick. From them, the superior took these items and assigned them to the sick ${ }^{16}$. If one of the nurses fell ill, the other nurses and the house superior took care of him ${ }^{17}$. The house superior also granted permission for relatives' visits of sick brothers ${ }^{18}$. During journeys, the weak and sick brothers remained under the care of persons appointed for weekly duty (hebdomadarii) ${ }^{19}$.

Among the food products served in the monastery, there were also some only served to the sick. As a rule, they included wine (vinum) and [fish] soup (liquamen) ${ }^{20}$. The soup could also be consumed by a friar who fell ill and stayed with the friars outside the monastery ${ }^{21}$. All the food that was delivered to the friary by the friars' relatives was also mostly for the sick ${ }^{22}$.

Monks were often seen as dirty and sloppy. They did not care about their appearance. This was due to the depreciation of the body, which they perceived as a source of temptation. Therefore, they avoided baths and did not rub the body with oil, so that the care for the body does not obscure the spiritual needs ${ }^{23}$. According to the Pachomian rule, hands should be washed and anointed after a day of work. It was not allowed to wash and anoint the whole body except for cases of visible illness ${ }^{24}$. Sick and elderly brothers were also allowed to rest in a closed chamber. ${ }^{25}$

\section{Rule of Saint Augustine}

While in Italy, Augustine became acquainted with the monastic movement even before his conversion. When he was in Milan, St. Augustine came into contact with St. Ambrose, who tried to organize monastic life there on his own. Perhaps Augustine knew about attempts to organize cenobitic life by Eusebius, Bishop of Vercellae. The story about St. Anthony the Hermit and monks living in Milan and Trier, told by Ponticianus, had a significant

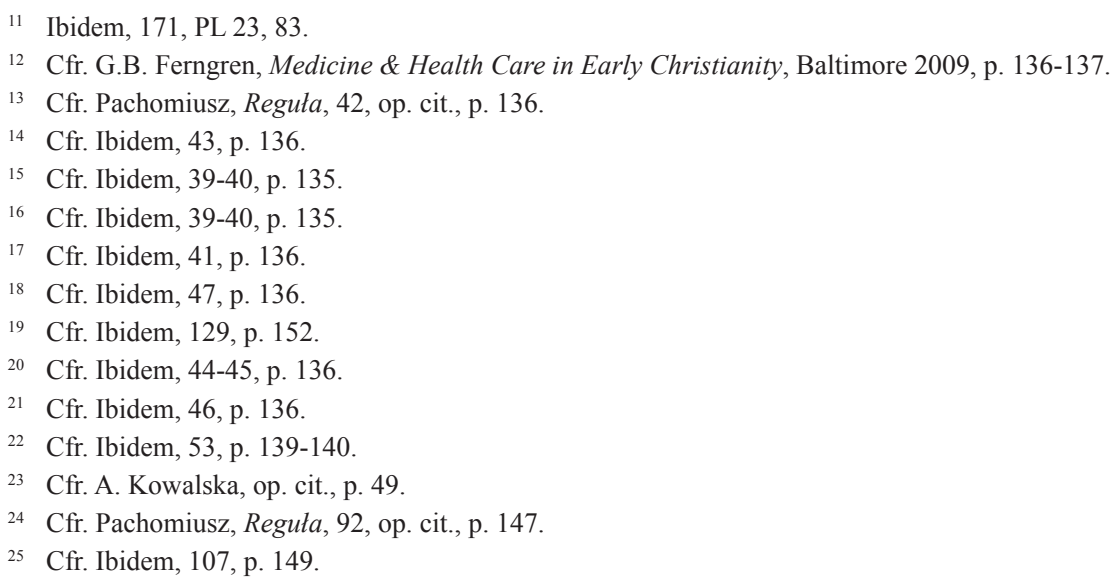


impact on the final act of conversion of Augustine. Withdrawing, together with his friends, to Cassiciacum and the stay there is considered to be the first stage of St. Augustine's monastic life. Once baptized, during his stay in Rome, Augustine visited many male and female monasteries and studied their way of life. Augustine realized the monastic ideals in his life after his return to Africa. He organized the first community in his native Thagaste (now Souk Ahras). After moving to Hippo, where he was ordained a priest, he established a monastery in this city, mainly for laypeople, although he did not exclude priests from $\mathrm{it}^{26}$.

Three works are considered fundamental for the Rule of St. Augustine: The Monastic Rule (Ordo monasterii), The Rule for Men (Praeceptum), and Letter 211, which includes Obiurgatio, which is a rebuke directed at disputing nuns, and Regularis informatio, which was the female variant of the men's rule mentioned above (Praeceptum $\left.{ }^{27}\right)$. The sick are only mentioned in Praeceptum.

As described in Praeceptum, there was a single person entrusted with care for the weak, the sick, as well as those who were recovering from illness. St. Augustine, however, did not specify more precisely who that person was and what functions he performed in the community. This person was also responsible for food supplies to the sick brothers ${ }^{28}$. The sick were also allowed to eat outside of meal hours ${ }^{29}$. Augustine also stressed the need to consult a doctor if someone suffers from a hidden diseas ${ }^{30}$. However, St. Augustine instructed his brothers that, after their recovery, they should abandon their predilection for the comforts that strengthened them when sick ${ }^{31}$. As we read in Praeceptum points out, Augustine took very good care of the hygiene of the friars in the monastery. Washing the whole body was very important, especially for the sick and when a doctor advised them to wash themselves: "Your bodies, too, need to be washed as their infirmity requires, and this should not be refused, but done without complaint according to medical advice, so that everyone, though unwillingly, does as his superior orders for the sake of his health. But if he wants to wash and doing so is bad for him, he ought not to give in to his own wishes, for sometimes he will think that what is pleasing is good, even if it may be harmful' ${ }^{\prime 32}$.

\footnotetext{
${ }^{26}$ Cfr. M. Starowieyski, Wprowadzenie [to Rule of St. Augustine] in: Starożytne reguty zakonne, ed. E. Stanula, Warsaw 1970, p. 73-75.

27 Cfr. P. Nehring, Prawodawstwo monastyczne św. Augustyna, in: Zachodnie reguly monastyczne, ed. M. Starowieyski, Kraków 2013, s. 228; G. Lawless, Przeglad monastycyzmu augustiańskiego i kilka sugestii co do dalszych badań, in: Duchowość starożytnego monastycyzmu. Materiaty z Międzynarodowej Sesji Naukowej, Kraków-Tyniec, 16-19 listopada 1994, ed. M. Starowieyski, Kraków 1995, p. 67-68.

${ }_{28}$ Cfr. Augustine, Rule(Praeceptum), V, 8, Polish translation used originally in this text: M. Starowieyski, P. Nehring, in: Zachodnie reguly monastyczne, op. cit., p. 273, English translation taken from "https://www.mostlymedieval.com/explore/prae.htm".

29 Cfr. Ibidem, III, 1, p. 266.

${ }^{30}$ Cfr. Ibidem, V, 6, p. 273.

31 Cfr. Ibidem, III, 5, p. 267.

32 Ibidem, V, 5, p. 273: "Lavacrum etiam corpori, cum infirmitatis necessitas cogit, minime denegetur Fiat sine murmure de consilio medici, ita ut etiam si nolit, jubente praeposito faciat quod faciendum est pro salute. Si autem velit, et forte non expedit, suae cupiditati non obediatur: aliquando enim etiam si noceat, prodesse tamen creditur quod delectat." Latin text: Augustinus, Regula, PL 32, 1379-1380.
} 


\section{The Rules of Caesarius of Arles}

Caesarius was born in 470 in the town of Cabillonum. Around the age of 20, he entered the abbey in Lérins. After a few years, he was sent by the abbot to Arles to improve his health impaired by ascetic practices. At the same time, the bishop of Arles, Eonius, included him among his clergymen. First, Caesarius became a deacon and then a priest. In 499 the bishop appointed him abbot in one of the monasteries in the suburb of Arles. Three years later, Eonius appointed Caesarius his successor, the bishop of Arles, and Caesarius began a nearly forty-year period of pastoral activity. He preached in towns and rural parishes and visited the ecclesiastical centres subordinate to him. As a bishop, and from 6th November 513 by the decision of Pope Symmachus the Metropolitan and Vicar of the Holy See and the Primate of Gaul and Spain, he organized Christian life in the area subordinate to him. To improve external conditions for the development of ecclesiastical life, he convened and presided over several synods, at which important decisions of an organizational and disciplinary nature were taken. Caesarius also significantly engaged in political and social activities. Using his moral authority, he contributed to the liberation of the inhabitants of the conquered cities, bailed out slaves with his property, and developed large-scale charitable activities necessary back then. He also organized monastic life in the subordinate area by building monasteries and writing rules for them. He died on 27 August $542^{33}$.

The literary monastic legacy of Caesarus of Arles consists of: Sermons (Sermones 233-238), Works for Nuns, Rules for Virgins, and Rule for Monks. Six of the so-called speeches of Caesarius of Arles addressed to the monks have been preserved with one of them, speech 233 , is a written dissertation, in ancient studies generally called a letter. It seems that five speeches were addressed to the monastic community near Arles, where Caesarius was an abbot, whereas speech 236 was delivered in Lérins. Speech 238 is different from the others, it is an occasional instruction on how to experience Lent. It is difficult to establish the dating of the speeches, but it seems that they date back to the period after 503 when Caesarius was already Bishop of Arles ${ }^{34}$. Works for Nuns is the first of our author's monastic texts intended for women and the predecessor of the Rule for nuns. Purity, the central virtue of female monasticism, is the most important theme of the Works ${ }^{35}$. The Rule for Virgins is the most important ascetic work of St. Caesarius, mostly because it is the first (not counting the female version of the Rule of Augustine) of its kind written especially for women ${ }^{36}$. Finally, Caesarius edited the Rule for Men in circumstances not known to us. Researchers used to consider it to be earlier than the Rule for Virgins, but Adalbert de Vogüe has proven the opposite. The Rule for Men was written between 534 and 542 It seems to be a new version of the female rule addressed to men. It has no specific addressee, so its tone is quite neutral compared to the Rule for Virgins. Rule for Men is a synthesis and summation of the monastic teaching of Caesarius of Arles ${ }^{37}$.

\footnotetext{
33 Cfr. T. Kołosowski, Kult chrześcijański w nauczaniu i działalności biskupa Cezarego z Arles, "Seminare", 15/1999, p. 305-306; ibidem, Działalność polityczno-społeczna biskupa Cezarego z Arles, "Saeculum Christianum", 1/1994, p. 55-64.

34 Cfr. J. Piłat, Wstęp, in: Cezary z Arles, Pisma monastyczne, ed. M. Starowieyski, Kraków 1994, p. 17.

35 Cfr. Ibidem, p. 20.

36 Cfr. Ibidem, p. 23.

37 Cfr. Ibidem, p. 27-28.
} 
The Rule for Virgins strongly emphasizes the obligation to care for sick sisters. Sisters who are sick or affected by any weakness were assigned a special guardian. Caesarius emphasizes that this should be a sister full of faithfulness, repentance, and sensitive to the needs of the sick. If special food is needed, the caregiver should turn to the housekeeper sister responsible for the pantry (cellaria). Caesarius even points out that, if needed, the monastery mother (mater monasterii) may designate a separate pantry and kitchen for the sick sisters ${ }^{38}$. The sick sisters also shared a special room where they stayed during their illness ${ }^{39}$. Both the caregiver and the housekeeper should treat care for the sick sisters as a priority: "As for the housekeeper and the one intended to serve the sick, they should be solemnly commanded before God and His angels to treat their care for the sick above every duty"40.

The sick sisters were not required to fast. However, the rule stipulates that this only applies to the period of illness. "When the [sick] sisters regain their former strength, let them return to regular, in which they find more happiness" ${ }^{\prime 4}$. Products that other sisters were not allowed to eat were also added to the menu of the sick In such a case, the abess (abbatissa) gave an order to eat meat ${ }^{42}$. When writing the Rule, Caesarius was aware that sick or weak sisters, out of shame, might not want to ask for an exception, so he addressed the following words to the sick and their caregivers: "And if out of shame, they do not dare to ask for an exception, you should order the housekeepers to give them meat, and tell them to accept it. And let them firmly believe that whatever they receive this food with the permission or by order of the superior, they receive Christ in this meal" ${ }^{43}$. The wine was also available in the monastery, which could be given to sick sisters and those who were brought up more gently ${ }^{44}$. With medical advice, the sick sisters were also obliged to use the bathhouse. Caesarius expressed this obligation as follows: "Thus, even if the sick does not wish to use the bathhouse herself let her, upon the order of her superior, do what she needs for her health ${ }^{45}$. However, using the bathhouse if not ill was considered a whim"46.

Given the extensive treatment of the issue of the sick in Regula ad virgines, the treatment of this subject in Regula ad monachos leaves a certain degree of hunger. This is because the

\footnotetext{
38 Cfr. Caesarius of Arles, Rules for the Nuns, [30] 32, Polish translation used: M. Borkowska, in: Zachodnie reguty monastyczne, op. cit., p. 419, English translation indirectly from Polish.

39 Cfr. Ibidem, [7] 9, p. 411.

40 Ibidem, [39] 42, p. 424. "Cellaria vero, et illa quae infirmis servitura est, super omnem sollicitudinem cura illis et diligentia infirmarum coram Deo et angelis ejus denuntietur. Latin text: Caesarius Arelatensis, Regula ad virgines", PL 67, 1115.

41 Cezary z Arles, Reguła dla dziewic, [20] 22, op. cit., p. 415 [Polish translation used as a source here]. "[...] sed cum vires pristinas reparaverint, redeant ad feliciorem abstinentiae consuetudinem." Latin text: Caesarius Arelatensis, Regula ad virgines, PL 67, 1110.

42 Cfr. Cezary z Arles, Reguła dla dziewic, 71, op. cit., p. 441-442 [Polish translation used as a source here].

43 Ibidem, [39] 42, p. 424. "[...] si illae propter verecundiam petere non praesumunt, vos eis jubeatis a cellariis dari, et ipsis ut accipiant ordinetis. Et certissime confidant, quidquid dispensante aut jubente seniore qualibet hora percipient, in illa repausatione Christum accipient." Latin text: Caesarius Arelatensis, Regula ad virgines, PL 67, 1115 .

44 Cfr. Cezary z Arles, Reguła dla dziewic, [28] 30, op. cit., p. 419 [Polish translation used as a source here].

45 Ibidem, [29] 31, p. 419. "[...] ita ut etsi lavare nollet illa quae infirma est, jubente seniore fiat quod opus fuerit pro salute." Latin text: Caesarius Arelatensis, Regula ad virgines, PL 67, 1112.

46 Cfr. Cezary z Arles, Reguła dla dziewic, [29] 31, op. cit, p. 419.
} 
issue is just treated with a single phrase: "The sick must be cared for in such a way that they can recover as soon as possible" ${ }^{47}$.

\section{Leander of Seville, Instruction of virgins and the contempt of the world}

Leander was born around 540, probably in Cartagena from his father Severianus, of IberoRoman origin, and a Visigoth mother. He had three younger siblings, brothers Fulgentius and Isidore, and a sister Florentine. Later the family moved to Baetica (now Andalusia) and then to Seville. There, his mother converted to Catholicism and Leander joined the monastery, where he received good spiritual formation. Around 577, he became the Archbishop of Seville and played an important role in political affairs. He dedicated his entire life to strengthening Catholicism in Spain. He died around 600 leaving his brother Isidore as his successor in the bishopric of Seville ${ }^{48}$.

Leander wrote the work De institutione virginum et de contemptu mundi in the first years of his episcopate when Catholicism was in danger. It is not a religious rule in the strict sense. The text does not have a character of a law. It is rather an invitation to Sister Florentine, who has just joined the monastery. Leander shows her the greatness and beauty of virginity. For virgins, Jesus Christ himself is the spouse, and His Mother is their patron saint. This work is very personal, full of personal commitment, and autobiographical elements. The second part, which contains 31 ascetic prescriptions, discusses the way virgins should act and the ascetic ideal of a nun ${ }^{49}$.

The fact that Leander's work is rather a treaty on virginity than a monastic rule is also evidenced by how sick sisters are treated in this work. Leander's words constitute a kind of advice on how his sister Florentine should relate to the sick sisters or how to behave in case of his own illness. She should be attentive and kind to sick sisters. She should treat other sisters' weaknesses and illnesses as her own. She should serve them not only in meeting their bodily needs during illness, but also provide them with spiritual support ${ }^{50}$. Leander instructs sick sisters to drink wine. However, they should drink it as a cure and not abuse it. On the contrary, a virgin in good health should completely avoid wine ${ }^{51}$. As for the consumption of meat by sick sisters, Leander is a little more restrained. He addresses Florentine directly saying that because of her poor health, he dares to neither forbid nor allow her to eat meat. Surely, a virgin in good health should refrain from consuming meat. In his persistent warning against the dangers of excessive meat consumption, he ultimately calls for restraint in this regard $^{52}$. Moreover, virgins should only take baths for health reasons. Illness should be the

\footnotetext{
47 Cezary z Arles, Reguła dla mnichów, 17, translated into Polish M. Borkowska, in: Zachodnie reguły monastyczne, op. cit., 2013, p. 455 [English translation based on Polish]. "Infirmi tractentur, ut citius convalescant." Latin text: Caesarius Arelatensis, Regula ad monachos, 17, PL 67, 1101.

48 Cfr. M. Kanior, op. cit., p. 225-226.

49 Cfr. ibidem, p. 226.

50 Cfr. Leander, O pouczeniu dziewic i o pogardzie świata, 4, translation into Polish I Gano, in: Zachodnie reguly monastyczne, op. cit., p. 948-949.

51 Cfr. Ibidem, 19, p. 962-964.

52 Cfr. Ibidem, 24, p. 970-972.
} 
only reason for frequent bathing. The care for the body, which comes from sensuality, should be considered a vice ${ }^{53}$.

\section{Isidore of Seville, Monastic rule}

Information on Isidore's life comes primarily from the List of the Books of Isidore Braulio of Zaragoza, which contains scarce information on his life, a detailed list, and description of his works, as well as the praise of Isidore, which is a valuable testimony to how Isidore, as shepherd and scholar, was perceived by his contemporaries. Other sources include the description of Isidore's death by Redemptus an otherwise unknown cleric, as well as the biography of the Bishop of Seville included in Ildefonsus's treaty De viris illustribus. Most scholars now accept the year 560 as his date of birth. Isidore's childhood and youth passed in the shadow of his great brother Leander. It can be assumed that these were years spent studying, reading the Holy Script, and the works of many Christian and pagan writers. This is evidenced by the "scientific" writings of Isidore. After Leander's death around 600, Isidore became bishop of Seville. As a bishop, Isidore presided over important church synods. He also participated in editing of Isidoriana, the oldest version of the first canonical collection of the West, the so-called Hispana, which included 105 papal decrees and 67 Eastern, African, Galician, and Spanish synods. It is also very likely that he also participated in editing the Latin translation of the Vetus Latina Hispana Bible. He was concerned with monastic life and education. He supported the poor, and, when he felt death coming, he handed out alms even more generously than he usually had done. He was a great preacher, he preached the Word of God with zeal and vigour. Braulio mentions that he was well-trained in every form of expression, and Ildefonsus testifies that the beauty of Isidore's sermons enchanted the listeners so much that they fell into a kind of stupor, so that after hearing it once they could not remember what was it actually about. Thanks to the extraordinary vigour and richness of his personality, Isidore took care of the Visigothic Kingdom, being an advisor to successive Visigothic kings. He died on 4th April 636 64.

Isidore discussed religious issues in many of his writings. A special expression of his interest in religious life was found in the rule that he wrote following the example of the writings of Augustine, John Cassian, Hieronymus, Benedict, and referring to his own experience. Isidore addressed his Monastic Rule to the monks from the Honorian Monastery of which we can only assume was located not far from Seville. In the following centuries, however, the works became known and were used by numerous monastic communities in Spain and beyond. Like other rules of the time, Isidore's work is not a code, but rather an eclectic collection of guidelines to help the community and its superiors. Isidore's Rule is human weaknesses being moderately and prudently taken into account. The Bishop of Seville has born it in mind that most of the monks came from the poorest, least educated social strata, and adapts the manner of expression to the level of his audience by writing in the folk language. He also allowed the monks a greater ration of wine than in other monasteries,

${ }_{53}$ Cfr. Ibidem, 20, p. 964-965.

${ }_{54}$ Cfr. T. Krynicka, Izydor z Sewilli, Kraków 2007, p. 6-15. 
did not require them to give up meat, and on feast days he ordered better food supplies for the monastery ${ }^{55}$.

How does the Monastic Rule resolve the question of living in a community of sick friars? A lot of attention is devoted to them there. A special caregiver was responsible for taking care of the sick. Isidore sees the role of a caregiver in the following manner: "The care of the sick should be entrusted to a monk of impeccable opinion, leading a saintly life, who would take care of them and do what their condition requires with great zeal" ${ }^{16}$. The primary task of the guardian was to ensure that the sick brothers receive milder meals until they returned to good health. The caregivers themselves are not allowed to consume the meals prepared for the sick. Healthy brothers should not be shocked that the sick are treated with more understanding ${ }^{57}$. After this remark, Isidore adds the following words: "It is unseemly of a man to hide a real disease or simulate an imaginary one. Those who are able to work should thank God and work, and those who are not should feel sorry for it and experience understanding" $" 58$. The sick should take the prescribed medication without a murmur with the goal of restoring health in mind Only the truly sick are allowed to enjoy baths for their health ${ }^{59}$. Moreover, they were the only ones allowed to eat outside of the meal hours set in the monastery ${ }^{60}$. Finally, the sick brothers were lodged in separate rooms (locus aegrotantium), away from the church, and other brothers' cells. Isidore just wanted nothing to disturb the peace of the sick ${ }^{61}$. With the abbot's permission, the sick and elderly brothers could live in separate cells (cellula separata) ${ }^{62}$.

\section{The Rule of Saint Benedict}

Knowledge on St. Benedict comes from the Book II of Dialogues by Gregory the Great. Benedict was born around 480 in Nursia, to a wealthy family of provincial nobility. Apart from the son, his parents also had a daughter Scholastica. Benedict received his first education in his family home. After completing studies in his home city of Nursia, at the age of about 14, he was sent to Rome for further studies. During his studies, he became familiar with reports on the life of Egyptian monks, but also with Manichaeans. Seeing the spreading evil, he considered his stay in this pagan city harmful and withdrew from the world. First, he joined a community of priests living at St. Peter's Church in Enfide in the Sabine Mountains. Later he moved to the deserted Subiaco Valley, located about $80 \mathrm{~km}$ east of Rome. There, he met an experienced Roman monk from a nearby monastery. Upon his advice, he settled in a rock

\footnotetext{
55 Cfr. Ibidem, p. 32-33.

56 Isidore of Seville, Monastic rule, 22, translated into Polish I. Gano, in: Zachodnie reguty monastyczne, op. cit., p. 1025, English translation indirectly from Polish. Cura infirmorum sanae sanctaeque conversationis viro committenda est, qui pro eis sollicitudinem ferre possit, magnaque cum industria praesto faciat quidquid imbecillitas eorum exposcit. Latin text: Isidorus, Regula monachorum, PL 83, 891.

57 Isidore of Seville, Monastic rule, 22, op. cit., p. 1026.

58 Isidore of Seville, Monastic rule, 22, op. cit., p. 1026. Nullum oportet vel veram corporis infirmitatem celare, vel falsam praetendere. Sed qui possunt Deo gratias agant, et operentur; qui vero non possunt manifestent suos languores, humaniusque tractentur. Latin text: Isidorus, Regula monachorum, PL 83, 891.

59 Cfr. Isidore of Seville, Monastic rule, 22, op. cit., p. 1026.

60 Cfr. Ibidem, 9, p. 1009

61 Cfr. Ibidem, 1, p. 994.

62 Cfr. Ibidem, 19, p. 1009.
} 
grotto, near the ruined palace of Nero, at the lake formed by the river Aniene, and began to lead an austere life of a hermit, like in the likeness of eastern monks. With time, the hermit became more and more famous in the area. The cave was no longer a hermitage because many monastic candidates wanted to submit themselves to his leadership. Thus, he gave up his lonely life and between 520 and 527 organized a life of recollection and prayer in 12 monasteries, under the leadership of an abbot appointed in each house. He reserved general management of houses and the formation of novices in the thirteenth monastery for himself. He probably used some kind of a rule, adapted to local conditions. It reminds us of the way of life according to the Rule of St. Pachomius. The jealousy and intrigues a clergyman from the neighborhood, who was trying to deprave his students, inclined Benedict to leave the Subiaco area. Together with a group of students, he moved to Monte Cassino, where on the ruins of the pagan temple of Jupiter and Apollo he built a church dedicated to St. John the Baptist and St. Martin. Next, a monastery was erected where Benedict organized community life, dedicated to prayer, especially liturgical, manual work, and spiritual reading. He died on 21 of March, probably $547^{63}$.

The Rule of St. Benedict consists of a prologue and 73 chapters, the last one being the epilogue. Benedict included the full code of the monk's life and the monk's duties there. The Rule was very practical in its character and was a manifestation of the evolution of monastic spirituality towards the mentality of Westerners. This practical character of the Rule allowed the people of the West to apply it directly, without prior adaptation, as opposed to the rules of St. Pachomius or St. Basil. The authenticity of the Rule of Saint Benedict has been confirmed. He wrote it in Monte Cassino at the end of his life. It is not a work that has been at once written in its entirety. As he gained more experience and precision of thought, the author not only corrected and supplemented the text, but he also added whole chapters ${ }^{64}$.

The Rule of St. Benedict entrusts the basic care of the sick is to the abbot (abbas). His role was to ensure that the sick are not neglected in any way ${ }^{65}$. The sick should be looked after in a special way by the monastic dispenser (cellararius) ${ }^{66}$ and a nurse (servitor) ${ }^{67}$. They should serve the sick with diligence and care. St. St. Benedict strongly emphasized the importance of care for the sick: "Before all things and above all things care is to be had of the sick, that they may be soserved as if they were in very deed Christ, because He Himself said: "I was sick and you looked after me" (Mt 25,36) and: "Truly I tell you, whatever you did for one of the least of these brothers and sisters of mine, you did for me" (Mt 25,40) ${ }^{68}$. However, Benedict called the brothers to show the virtue of patience in the face of illness. This applies to both the sick and the brothers who care for them: "But at the same time let the sick themselves have in mind that it is for God's honour they are served and so let them not with unnecessary demands weary their brethren who serve them. Yet they must be patiently

\footnotetext{
63 Cfr. M. Kanior, op. cit., p. 172-174.

64 Cfr. Ibidem, p. 175-176.

${ }^{65}$ Cfr. Saint Benedict of Nursia, The Rule, 36, translated A Świderkówna, Kraków 1994, p. 152 (Polish and Latin; Enlish translation from https:/www.solesmes.com/sites/default/files/upload/pdf/rule_of_st_benedict.pdf)

${ }^{66}$ Cfr. Ibidem, 31, p. 141.

${ }_{67}$ Cfr. Ibidem, 36, p. 154-155.

68 Ibidem, 36, p. 152: Infirmorum cura ante omnia et super omnia adhibenda est, ut sicut revera Christo, ita eis serviatur, quia ipse dixit: "Infirmus fui et visitastis me»; et: "Quod fecistis uni de his minimis, mihi fecistis».
} 
borne with because from such is acquired more abundant merit" ${ }^{\prime 69}$. Sick brothers should have a cell designated individually for them ${ }^{70}$. They should also have access to a bath: "as often as is expedient"71. Customarily, monks living according to the Rule of St. Benedict did not eat meat. However, the sick could obtain permission to eat meat when ill ${ }^{72}$. It could even have been pet meat ${ }^{73}$. Should the sick brothers work? Benedict does not allow backbreaking work to them. However, they should be given a job so that they do not risk staying inactive ${ }^{74}$.

\section{Conclusions}

What was the care for the sick in ancient male and female monasteries like in the light of the monastic rules that we analysed? Each of the rules designated from among the brothers or sisters a special person to take care of the sick. Some of the rules did not provide for a precise definition of the function of this person in the monastery, nor did they define in more detail the tasks associated with serving the sick (The Rule of St. Augustine). Caesarius of Arles in his Rule for Virgins specifies the characteristics that a caregiver of the sick should have, and Isidore of Seville also defines his or her duties. Pachomius and Benedict define the caregiver's role more precisely. Pachomius entrusts the general care to the house superior (praepositus) and the nurses (ministri aegrotantium). Benedict entrusts the abbot (abbas) with the primary care of the sick and appoints a housekeeper and a nurse as special caregivers.

As a rule, a separate room was designated for the sick. It was a special room or cell intended exclusively for the sick (Pachomius, Caesarius of Arles, Isidore of Seville, Benedict). In some cases, the patients had a separate dining room, pantry or kitchen (Pachomius, Caesarius of Arles) intended only for them.

All the rules also provide for the relaxation of the requirements concerning eating, fasting, and bathing for the sick. Augustine and Isidore emphasize that patients may eat outside meal hours. Isidore also discussed the need to serve more delicate meals to the sick but does not provide any more details about the patients' diet. Some rules indicate foods that could be eaten by the sick but not by other monks or virgins. Pachomius provides for wine and soup especially for the sick. Caesarius of Arles releases the virgins from fasting and allows them to consume wine and meat. Benedict also allows the sick brothers to eat meat, while Leander even recommends the sick sisters to drink wine.

In all the monasteries, the use of the bath was at least a very restrained if not prohibited for healthy monks and nuns. An exception was made for the sick. Only they were allowed to enjoy baths for their health. In this case, the authors of religious rules considered bathing to be necessary, especially if prescribed by a doctor.

The patients were also exempted from work, especially from strenuous work. As indicated at least in the rules of Augustine and Isidore, some monks may have simulated the disease to avoid work. Therefore, often the sick were often not completely released from work. This

${ }_{69}$ Ibidem, 36, p. 152: Sed et ipsi infirmi considerent in honorem Dei sibi servire et non superfluitate sua contristent fratres suos servientes sibi. Qui tamen patienter portandi sunt, quia de talibus copiosior mercis adquiritur.

70 Cfr. Ibidem, 36, p. 154-155.

71 Ibidem, 36, p. 154-155: [...] quotiens expedit [...].

72 Cfr. Ibidem, 36, p. 154-155.

73 Cfr. Ibidem, 39, p. 162-163.

${ }^{74}$ Cfr. Ibidem, 41, p. 166-167. 
is why, as St. Benedict, in particular, suggests, the inhabitants of the monasteries should at least do some light work to avoid inactivity.

It is important to realize that the monastic rules do not reveal the whole reality about sick monks or virgins in monasteries. Because of their normative nature, they establish principles only for the most important issues concerning the lives of the sick in individual monastic communities. Therefore, they did not discuss many issues related to illness and health in monasteries. We know little about what healthcare in monasteries looked like. Some rules occasionally mention doctors who recommend a bath to the sick. The rules themselves do not contain any more information on them. Did the monasteries have their doctors, or were the monastery residents treated by the doctors from the outside? What medications did they prescribe to the sick? Was there any other treatment used for the sick? Which were the most frequent diseases? Can we talk about health prevention? These are just some of the questions that cannot be answered when reading the monastic rules.

\section{Care of the sick in ancient monasteries life in the light of selected monastic rules Summary}

This article attempts to answer the question of how Eastern and Western monastic rules provided for the sick in ancient monasteries. Did they enjoy any kind of special status among their brothers or sisters? Who was responsible for the sick in the monastery and how they took care of the ill? In this regard, monastic rules are an interesting and unique source of information about activities undertaken to care for ill members of the monastic community. We identified and analysed seven monastic rules. These rules were written in different regions of the contemporary world: Egypt, North Africa, Gaul, Italy, and Spain. One was written in the $4^{\text {th }}$, and the other in the $7^{\text {th }}$ century, and both concern monks and consecrated women. Each rule appoints some individuals responsible for the care of the sick. These were usually nurses and monastic dispensers. Some rules determined the required personality traits. The general supervision over the care of the sick was entrusted to the monastery superior. Separate rooms or cells were designated for the sick, sometimes together with a dining room, pantry, or kitchen. All the rules seek to ease the requirements concerning the consumption of meals, fasts, and hygiene for the sick. If capable, they should engage in lighter works.

Keywords: monasticism, monasteries, monastic rules, ill, the illness

About the author: Ks. dr hab. Tadeusz Kołosowski is a researcher and lecturer at the Faculty of History Cardinal Stefan Wyszyński University in Warsaw, a university professor in the Department of Ancient History. His research interests focus on the history of contemporary Christianity and early Christian literature.

Translated by Józef Jaskulski 